P-ISSN:

E-ISSN:

Email: ristansi@asia.ac.id

https://jurnal.stie.asia.ac.id/index.php/ristansi

\title{
DAMPAK PANDEMI COVID-19 TERHADAP UMKM BATIK DI KABUPATEN SUMENEP
}

\author{
Rosa Nindia Sari, Alwiyah \\ Universitas Wiraraja Madura \\ Alamat surel : rnindiasari24@gmail.com
}

DOI: doi.org//xxxxx

Informasi Artikel

\begin{tabular}{ll}
\hline Tanggal Masuk & November \\
& $19^{\text {th }}, 2020$ \\
Tanggal Revisi & December \\
& $1^{\text {st }}, 2020$ \\
Tanggal diterima & December \\
& $14^{\text {th }}, 2020$
\end{tabular}

Keywods:

Impact of Covid-19

Batik SMES

Government Policy

\section{Abstract:}

Covid-19 is a type of virus originating from the Chinese city of Wuhan. During the Covid-19 Pandemic, the government issued regulations to implement physical distancing, large-scale social restrictions or PSBB and the closure of the tourism sector, and the government has cut official budgets that will be diverted for handling Covid-19. This has an impact on the sustainability of the batik SMES business in Sumenep district. Because various events and activities are currently being eliminated, such as official visits bringing regional souvenirs, excursions to craftsmen, wedding receptions, and ordering official uniforms. In this study, the authors used a qualitative research type with a case study approach. The data validity test used the data source triangulation technique. The results of this study indicate that the Covid-19 Pandemic has an impact on batik SMES in Sumenep district. Where is the current impact on the decline in sales, acquisition of raw materials, accounts receivable, and employee salary payments. For the sake of business continuity, batik SMES in Sumenep district use social media as a means of online marketing. The hope of batik SMES in Sumenep district is that they will receive assistance from the government during the Covid-19 Pandemic. Now, UD. AI Barokah, CV. Batik Tulis Melati, and Canteng Koneng received credit restructuring from the government.
Kata Kunci:

Dampak Covid-19

UMKM Batik

Kebijakan Pemerintah

\section{Abstrak:}

Covid-19 merupakan sejenis virus yang berasal dari kota Wuhan China. Disaat Pandemi Covid-19 pemerintah mengeluarkan peraturan untuk menerapkan physical Distancing, Pembatasan Sosial Berskala Besar atau PSBB dan tutupnya sektor pariwisata, serta pemerintah telah memangkas anggaran dinas yang akan dialihkan untuk penanganan Covid-19. Hal tersebut sangatlah 
berdampak terhadap keberlangsungan usaha UMKM Batik di kabupaten Sumenep. Karena berbagai acara maupun kegiatan saat ini ditiadakan seperti adanya kunjungan dinas yang membawa oleh-oleh khas daerah, kunjungan pariwisata kepada pengrajin, acara resepsi pernikahan, dan pemesanan seragam dinas. Pada penelitian ini, penulis menggunakan jenis penelitian kualitatif dengan pendekatan studi kasus. Uji keabsahan data menggunakan teknik triangulasi sumber data. Hasil penelitian ini menunjukkan bahwa adanya Pandemi Covid-19 sangatlah berdampak terhadap UMKM Batik di kabupaten Sumenep. Dimana dampak yang dialaminya saat ini pada penurunan penjualan, perolehan bahan baku, piutang, dan pembayaran gaji karyawan. Demi keberlangsungan usahanya, UMKM Batik di kabupaten Sumenep menggunakan media sosial sebagai sarana pemasaran online. Harapan UMKM Batik di kabupaten Sumenep adanya bantuan dari pemerintah dimasa Pandemi Covid-19. Kini, UD. Al Barokah, CV. Batik Tulis Melati, dan Canteng Koneng menerima bantuan dari pemerintah berupa restrukturisasi kredit.

\section{PENDAHULUAN}

Adanya Pandemi Covid-19 bukan hanya berdampak pada aspek kesehatan, akan tetapi juga berdampak pada perekonomian global. World Bank memperkirakan ekonomi global akan menyusut 5,2\% tahun ini. Produk Domestik Bruto atau Gross Domestik Bruto di berbagai negara diperkirakan akan berkontraksi akibat permintaan, pemasokan, perdagangan, dan keuangan sangat terganggu akibat Pandemi Covid-19 (Hadad, 2020).

Pertumbuhan ekonomi Indonesia pada Q1-2020 Year On Year masih relatif baik dengan pertumbuhan Produk Domestik Bruto (PDB) berkisar 2,97. Namun saat ini domestik ekonomi di Indonesia mengalami destruktif dari sisi Supply and Demand. Dari sisi Supply produsen mengalami kesulitan dalam perolehan bahan baku, karena hampir $60 \%$ bahan baku diperoleh dari impor. Saat ini industri yang masih dapat bertahan dimasa Pandemi Covid-19 yang perolehan bahan bakunya berasal dari lokal, sedangkan dari sisi Demand para pelaku usaha mengalami penurunan terhadap permintaan (Ananda, 2020).

Saat ini terdapat 75\% UMKM mengalami penurunan dari penjualan dan keuntungannya turun bisa lebih dari 50\%. Kemudian dari 58,76\% UMKM memutuskan untuk menurunkan harga untuk mempertahankan usahanya. UMKM dari kelompok mikro dan ultramikro yang mengandalkan penjualan secara fisik atau toko cenderung mengalami penurunan penjulan lebih dari 75\% (Ananda, 2020).

Disaat Pandemi Covid-19 pemerintah telah mengeluarkan stimulus untuk UMKM yang alokasinya berkisar 123,46 Triliun. Stimulus fiskal yang diberikan pemerintah untuk UMKM berupa subsidi bunga, belanja UP, PPh final UKM DTP, penepatan dana untuk rekstrukturisasi, penjaminan untuk modal kerja, pembiayaan investasi kepada koperasi melalui LPDB KUMKM. Namun saat ini anggaran stimulus untuk UMKM belum seluruhnya terealisasi. Anggaran tersebut hanya terealisasi sebesar 0,06\% (Rachbini, 2020). 
Saat ini terdapat sebagian pelaku UMKM di kabupaten Sumenep yang telah mengajukan bantuan untuk mempertahankan usahanya. Berdasarkan data yang diperoleh dari Dinas Koperasi dan Usaha Mikro bahwa terdapat 3.529 UMKM di Kabupaten Sumenep, pelaku UMKM yang mengajukan bantuan kepada Dinas Koperasi dan Usaha Mikro berjumlah 350 UMKM. Penurunan penjualan yang dialami UMKM disebabkan adanya peraturan pemerintah untuk menerapkan physical Distancing, Pembatasan Sosial Berskala Besar atau PSBB dan tutupnya sektor pariwisata. Sehingga saat ini masyarakat luar daerah dan masyarakat mancanegara tidak dapat berkunjung untuk berwisata.

Adanya kunjungan pariwisata dapat menjadi peluang untuk UMKM dalam memasarkan produknya terutama pada UMKM Batik. Dimana produk batik saat ini banyak diincar oleh para wisatawan. Batik memiliki fungsi praktis dan estetis. Secara praktis batik dapat digunakan sebagai bahan pakaian, sedangkan secara estesis batik memiliki nilai seni yang tinggi. Apalagi eksistensi batik dikenal oleh dunia setelah mendapatkan pengakuan dari UNESCO.

Pengakuan UNESCO terhadap batik Indonesia itu disambut baik oleh pemerintah dengan mengeluarkan Keputusan Presiden Republik Indonesia Nomor 33 Tahun 2009 tentang Hari Batik Nasional. Berdasarkan Kepres tersebut, tanggal 2 Oktober dipilih sebagai Hari Batik Nasional dengan harapan dapat mendorong bangsa Indonesia agar terus melestarikan dan mengembangkan kerajinan batik. (Alwiyah, 2017).

Setelah ditetapkannya hari batik oleh pemerintah pada 2 Oktober, kini batik banyak digunakan sebagai pakaian resmi oleh Aparatur Sipil Negara (ASN). Namun adanya Pandemi Covid-19 kini pemerintah telah memangkas anggaran dinas yang akan dialihkan untuk penanganan Covid-19. Sehingga untuk saat ini pemesanan seragam dinas telah terhenti. Kegiatan seperti kunjungan dinas yang membawa oleh-oleh khas daerah, kunjungan pariwisata kepada pengrajin, acara resepsi pernikahan telah ditiadakan. Hal tersebut sangatlah berdampak pada penurunan penjualan yang dialami oleh pelaku UMKM Batik.

Penurunan penjualan yang dialami oleh UMKM Batik di kabupaten Sumenep akan berimbas kepada nasib karyawan dan pengrajin yang bekerja pada UMKM tersebut. Dimana saat ini terdapat sebagian para karyawan dan pengrajin diberhentikan untuk sementara waktu. Tindakan untuk memberhentikan sebagian karyawan dan pengrajin dilakukan karena terjadinya penumpukan stok dan pengeluaran lebih besar dari pada pendapatan yang diperolehnya. Hal tersebut disebabkan turunnya permintaan dari konsumen. Sehingga pemilik UMKM mengalami kendala pada pendanaan.

Rumusan masalah pada penelitian ini ialah bagaimana dampak Pandemi Covid- 19 terhadap UMKM Batik di kabupaten Sumenep, bagaimana UMKM Batik dapat mempertahankan usahanya disaat Pandemi Covid-19, apa harapan UMKM Batik pada pemerintah disaat Pandemi Covid-19.

Berdasarkan rumusan masalah pada penelitian ini, maka tujuan penelitian ialah untuk mendeskripsikan dampak Pandemi Covid-19 terhadap UMKM Batik di kabupaten Sumenep, untuk mendeskripsikan UMKM Batik dapat mempertahankan usahanya dan untuk mendeskripsikan harapan UMKM Batik pada pemerintah disaat Pandemi Covid19.

\section{TINJAUAN PUSTAKA}

\section{Teori Strategi Pemasaran (Marketing Strategi)}

Teori strategi pemasaran (Marketing Strategi) dikemukakan oleh Suharyadi et al., 2007 suatu cara yang digunakan untuk membantu kita membuat dan menjual barang 
dan jasa yang sesuai dengan kondisi perusahaan dan pasar target atau selera konsumen yang dituju.

\section{Teori Permintaan}

Teori Permintaan dikemukakan oleh Sarjono, 2017 permintaan akan suatu barang dan jasa timbul dari kebutuhan konsumen untuk menguasai barang dan jasa tersebut, keinginan ini timbul karena barang dan jasa itu mempunyai nilai.

\section{Teori Kebijakan Publik}

Kebijakan publik dikemukakan oleh Islamy, 2010 kebijakan publik sebagai kebijakan negara dalam bentuk awalnya berupa ketetapan tindakan-tindakan pemerintah, kebijakan negara tidak cukup hanya dinyatakan, tetapi harus dilaksanakan dalam bentuk yang nyata, kebijakan negara yang baik untuk melakukan sesuatu atau tidak melakukan sesuatu dilandasi dengan maksud dan tujuan tertentu, kebijakan negara harus senantiasa ditujukan bagi pemenuhan kepentingan seluruh anggota masyarakat.

\section{Pengertian Usaha Mikro Kecil Dan Menengah}

Pengertian Usaha Mikro Kecil dan Menengah yang sering disingkat UMKM disetiap Negara berbeda-beda, indikatornya juga tidak sama. Di Negara kita pengertian Usaha Mikro Kecil dan Menengah dijelaskan di undang-undang No. 20 tahun 2008 yaitu dilihat dari jumlah karyawan atau tenaga kerja yang dimiliki. UMKM adalah Usaha Mikro Kecil dan Menengah Usaha Mikro yaitu:

1. Usaha yang mempunyai karyawan maksimum 4 orang. Usaha kecil yaitu usaha yang jumlah karyawannya antara 4 sampai 19 orang. Usaha menengah jumlah karyawannya minimal 20 orang dan maksimal 100 orang.

2. Meski dikelola dengan sederhana, pada saat itu mereka telah mengambil peran besar dan tidak menjadi beban pemerintah.

3. Pada saat sekarang Ekonomi UMKM menjadi tumpuan dan menjadi pilihan penting bagi para sarjana untuk hidup lebih sejahtera, mandiri dan menolong banyak orang mengatasi pengangguran.

4. UMKM mempunyai kontribusi yang sangat besar terhadap produk domestik bruto.

Berdasarkan jumlah aset dan omset penjualannya kriteria UMKM sebagai berikut:

1. Kekayaan bersih paling banyak 50 juta rupiah tidak termasuk tanah dan bangunan tempat usaha atau memiliki hasil penjualan tahunan paling banyak 300 juta rupiah.

2. Kriteria usaha kecil memiliki kekayaan bersih lebih dari 50 juta rupiah sampai dengan paling banyak 500 juta rupiah tidak termasuk tanah dan bangunan tempat usaha atau memiliki hasil penjualan tahunan lebih dari 300 juta rupiah sampai dengan paling banyak dua miliar lima ratus juta rupiah.

3. Kriteria usaha menengah memiliki kekayaan bersih lebih dari 500 juta rupiah sampai dengan paling banyak 10 miliar rupiah tidak termasuk tanah dan bangunan tempat usaha atau memiliki hasil penjualan tahunan lebih dari dua miliar lima ratus juta rupiah sampai dengan paling banyak lima puluh miliar rupiah. (Darmanto et al., 2018).

\section{Peluang Batik Madura}

Batik di Madura memiliki peluang untuk terus berkembang, selain karena namanya yang sudah dikenal dunia, juga berjalin-kelindan dengan perkembangan sektor pariwisata di Madura. Kehadiran wisatawan ke Madura tentu akan membawa dampak terhadap para pengrajin batik. Dengan catatan, para pengrajin batik mampu membaca dan memanfaatkan peluang dengan baik. Wisatawan yang berkunjung ke Madura tidak 
hanya ingin melepas penat, tapi ingin pulang membawa oleh-oleh dari Madura; batik bisa dipasarkan sebagai oleh-oleh mereka ke kampung halamannya (Alwiyah, 2017).

\section{Proses Produksi Batik, Bahan Baku, Dan Hasilnya}

Jumlah batik yang berhasil diproduksi oleh para pengrajin batik di desa Pakandangan Barat, Kabupaten Sumenep juga terus mengalami peningkatan. Bahkan produksi batik tulis di desa pakandangan barat mencapai puluhan pengusaha. Untuk kebutuhan membuat batik, para pengrajin di desa Pakandangan Barat, Sumenep membutuhkan input berupa bahan baku dan beragam kebutuhan untuk seluruh proses membatik, yang meliputi bahan baku (kain), bahan penolong (malam, bahan pewarna alami, dan pewarnaan kimia, perlengkapan membatik, canting, tungku, dandang, panci, tempat pencelupan, tempat penjemuran, plastis kemasan, tempat penyimpanan, dan lain-lain), pengrajin (penduduk yang membatik), tempat untuk membatik (asset tetap, yaitu rumah pengusaha), dana personal, dan kemampuan manajerial pengusaha (Alwiyah, 2017).

\section{Geliat Pemasaran Batik Madura}

Pemasaran online biasanya lebih digandrungi pelaku usaha batik yang belum terlalu dikenal banyak orang. Adanya online marketing telah menjadi sebuah metode yang paling efisien dalam layanan penjualan produk maupun jasa. Namun, para pengrajin batik di Madura belum maksimal memanfaatkan teknologi informasi untuk memasarkan produknya secara online. Salah satu kekurangan dari pemasaran online karena masih banyak para pelanggan yang menggunakan media hanya untuk memiliki informasi lebih lanjut mengenai sebuah produk. Setelah tahu, mereka lebih memilih untuk membeli secara langsung. Promosi batik melalui sistem online terkadang hanya dijadikan perbandingan (Alwiyah, 2017).

\section{METODE PENELITIAN}

Pada penelitian ini, penulis menggunakan jenis penelitian kualitatif dengan pendekatan studi kasus dimana penulis menggali informasi mengenai permasalahan yang dialami oleh UMKM Batik di kabupaten Sumenep selama masa Pandemi Covid-19, kemudian penulis menarik kesimpulan terhadap kasus tersebut.

Jenis data yang digunakan ialah data subjek. Data tersebut berupa informasi yang didapatkan dari pelaku UMKM Batik mengenai dampak Pandemi Covid-19 terhadap usaha yang dirintisnya. Sumber data yang digunakan pada penelitian ini ialah data primer. Data diperoleh dari hasil wawancara pada pemilik UD. Barokah, CV. Batik Tulis Melati, dan Canteng Koneng.

Dalam pengumpulan data peneliti terjun langsung kelapangan untuk memperoleh data yang diinginkan. Teknik pengumpulan data pada penelitian ini dengan cara Observasi, Wawancara, dan dokumentasi.

Teknik analisis data pada penelitian ini menggunakan model Miles and Huberman. Menurut (Sugiono, 2019) model Miles and Huberman merupakan teknik analisis data kualitatif yang dilakukan secara interaktif dan berlangsung secara terus menerus sampai tuntas, sehingga datanya sudah jenuh. Teknik analisis data Miles and Huberman terdiri dari Reduksi Data, Penyajian Data, Kesimpulan dan Verifikasi.

Uji keabsahan data pada penelitian ini menggunakan teknik triangulasi sumber. Teknik ini digunakan untuk mendapatkan data dari sumber yang berbeda dengan teknik yang sama. Dimana penelitian ini dilakukan pada UD. Al Barokah, CV. Batik Melati, dan Canteng Koneng. 


\section{HASIL DAN PEMBAHASAN}

Dampak Pandemi Covid-19 terhadap UMKM Batik di kabupaten Sumenep

Pandemi Covid-19 menjadi suatu ancaman bagi para pelaku UMKM Batik di kabupaten Sumenep. Adanya Pandemi Covid-19 ini menjadi suatu kendala bagi UMKM Batik dalam menjalankan usahanya. Kendala yang dialami oleh UMKM Batik sebagai berikut:

\section{a. Penurunan Penjualan}

Disaat Pandemi Covid-19 UD. Al Barokah, CV. Batik Tulis Melati dan Canteng Koneng mengalami penurunan penjualan. Penurunan penjualan yang dialaminya akan berimbas pada para pengrajin dan karyawan yang bekerja di UMKM tersebut. Dimana pemilik UD Al Barokah telah memberhentikan separuh dari pengrajin yang bekerja. Tindakan tersebut juga dilakukan oleh pemilik CV. Batik Tulis Melati. Seluruh para karyawan dan pengrajin telah diberhentikan. Karena disaat Pandemi Covid-19 tidak ada pengunjung dari luar daerah dan mancanegara yang membeli produknya. Namun tindakan untuk memberhentikan para karyawan dan pengrajin dimasa pendemi Covid-19 tidak dilakukan oleh pemilik Canteng Koneng.

Penurunan penjualan yang dialami oleh UD. Al Barokah, CV. Batik Tulis Melati dan Canteng Koneng disebabkan adanya penerapan PSBB dan tutupnya sektor pariwisata dimasa Pandemi Covid-19. Adanya pariwisata dapat dijadikan peluang bagi UMKM Batik untuk menjual produknya karena wisatawan yang berkunjung akan mencari oleh-oleh untuk di bawah pulang. Apalagi batik mempunyai fungsi praktis dan fungsi estetis. Fungsi praktis dari batik dapat digunakan sebagai pakaian, sedangkan fungsi

estetis dari batik dapat digunakan sebagai karya seni hias yang memiliki pesan moral. Hal tersebut sejalan dengan Teori Permintaan yang dikemukakan oleh (Sarjono, 2017) permintaan akan suatu barang dan jasa timbul dari kebutuhan konsumen untuk menguasai barang dan jasa tersebut, keinginan ini timbul karena barang dan jasa itu mempunyai nilai.

\section{b. Perolehan Bahan Baku}

Bahan baku merupakan bahan yang dibutuhkan dalam melakukan proses produksi. Tanpa adanya bahan baku dapat menghambat proses produksi. Disaat Pandemi Covid-19 terdapat sebagian UMKM Batik mengalami kendala pada saat perolehan bahan baku. Kendala pada saat perolehan bahan baku telah dialami oleh pemilik UD. Al Barokah dan Canteng Koneng. UD. Al Barokah mengalami kendala kenaikan harga pada saat perolehan bahan baku. Disaat Pandemi Covid19 harga kain dan pewarna batik melonjak naik. Sedangkan pemilik Canteng Koneng mengalami kendala telatnya pengiriman bahan baku karena telatnya pengiriman barang. Pada saat itu pemilik Canteng Koneng terpaksa membeli bahan pewarna lain untuk membuat batik. Sehingga barang yang diproduksinya banyak yang rusak. Akibat bahan pewarna batik yang digunakan tidak sama dengan bahan pewarna yang digunakan sebelumnya.

Kendala pada saat perolehan bahan baku tidak dialami oleh pemilik CV. Batik Tulis Melati. Karena ia sudah mempunyai supplierdalam perolehan bahan baku. Bahan bakunya diperoleh dari Pamekasan, Surabaya, dan Solo.

\section{c. Penagihan Piutang}

Disaat Pandemi Covid-19 terdapat sebagian UMKM mengalami kendala dalam penagihan piutang. Kendala dalam penagihan piutang saat ini telah dialami oleh UD. Al Barokah. Adanya Pandemi Covid-19 dapat dijadikan suatu 
alasan oleh pelanggan untuk menunggak pembayaran piutang. Hal tersebut disebabkan karena pelanggan ataupun agen saat ini terdampak Covid-19 sehingga mereka tidak mampu untuk membayar piutang mereka kepada UD. Al Barokah. Kendala dalam penagihan piutang tidak dialami oleh CV. Batik Tulis Melati dan Canteng Koneng.

\section{d. Pembayaran Gaji Karyawan}

UD. Al Barokah pernah mengalami kendala dalam membayar gaji karyawannya. Hal tersebut terjadi karena saat itu tidak ada pendapatan akibat tidak adanya permintaan dari konsumen. Kendala dalam membayar gaji karyawan juga dialami oleh Canteng Koneng. Kendala tersebut terjadi bukan hanya disebabkan oleh Pandemi Covid-19 saja, tetapi juga disebabkan oleh faktor cuaca. Karena barang yang diproduksinya banyak yang rusak. Sehingga pengeluaran pada saat itu tidak sebanding dengan pendapatannya, apalagi saat itu Canteng Koneng mengalami penurunan penjulan akibat Pandemi Covid-19. Demi mengurangi beban operasionalnya UD. Al Barokah dan Canteng Koneng menunda pembayaran gaji karyawan untuk sementara waktu selama satu bulan. Kendala terhadap pembayaran gaji karyawan tidak dialami oleh CV. Batik Tulis Melati, karena selama masa Pandemi Covid-19 proses produksi dihentikan karena tidak adanya permintaan dari konsumen.

\section{Langkah Yang Dilakukan UMKM Dalam Mempertahankan Usahanya}

Adanya peraturan pemerintah mengenai penerapan Pembatasan Sosial Berskala Besar atau PSBB dan tutupnya sektor pariwisata menjadi suatu kendala UMKM Batik dalam menjual produknya. Karena saat ini tidak ada kunjungan pariwisatawan dari luar daerah ataupun mancanegara. Demi mempertahankan usahanya UD. Al Barokah, CV. Batik Tulis Melati, dan Canteng Koneng menggunakan media sosial untuk memasarkan produknya secara online. Pemasaran secara online dilakukan agar usahanya tidak stagnan akibat adanya Pandemi Covid-19 dan tetap menjalin komunikasi dengan konsumen, serta mempromosikan produk barunya. Hal ini sejalan dengan teori stategi pemasaran yang dikemukakan oleh Suharyadi et al., 2007 suatu cara yang digunakan untuk membantu kita membuat dan menjual barang dan jasa yang sesuai dengan kondisi perusahaan dan pasar target atau selera konsumen yang dituju.

UMKM Batik dikabupaten Sumenep hanya menggunakan media sosial seperti Whatsapp sebagai alat komunikasi kepada konsumen seperti yang dilakukan oleh pemilik UD Al. Barokah, sedangkan Canteng Koneng hanya mempromosikan produknya di Instagram. Namun hal tersebut tidak berjalan secara efektif. Seharusnya mereka juga memanfaatkan plafon Shopee, Tokopedia, Buka Lapak, Blibli, dan Lazada yang saat ini telah digandrungi oleh masyarakat untuk belanja online di masa Pandemi Covid-19.

\section{Harapan UMKM Pada Pemerintah}

Disaat Pandemi Covid-19 pemilik UD. Al Barokah dan CV. Batik Tulis Melati tidak mengharapkan bantuan dari pemerintah terhadap usahanya. Justru pemilik UD. Al Barokah Berharap adanya bantuan untuk membantu UMKM yang usahanya masih kecil dan para pengrajin yang diberhentikan. Adanya bantuan dari pengrajin juga diharapkan oleh pemilik CV. Batik Tulis Melati. Beda halnya dengan pemilik Canteng Koneng. Ia berharap agar pemerintah dapat mencari solusi untuk membantu UMKM disaat Pandemi Covid-19. Bantuan yang diinginkan oleh Canteng Koneng berupa bahan baku dan bantuan biaya operasional produksi.

Saat ini pemerintah telah mengeluarkan stimulus fiskal untuk membantu UMKM. Adanya kebijakan tersebut dapat membantu UMKM agar dapat mempertahankan 
usahanya disaat pendemi Covid-19. Hal ini sejalan dengan teori kebijakan publik yang dikemukakan oleh Islamy, 2010 kebijakan publik sebagai kebijakan negara dalam bentuk awalnya berupa ketetapan tindakan-tindakan pemerintah, kebijakan negara tidak cukup hanya dinyatakan, tetapi harus dilaksanakan dalam bentuk yang nyata, kebijakan negara yang baik untuk melakukan sesuatu atau tidak melakukan sesuatu dilandasi dengan maksud dan tujuan tertentu, kebijakan negara harus senantiasa ditujukan bagi pemenuhan kepentingan seluruh anggota masyarakat.

Bantuan dari pemerintah yang diterima oleh UD. Al Barokah, CV. Batik Tulis Melati dan Canteng Koneng saat ini berupa stimulus untuk rekstrukturisasi kredit. Dimana UD. Al Barokah, CV. Batik Tulis Melati dan Canteng Koneng hanya mendapatkan keringanan untuk membayar bunga kredit saja.

\section{KESIMPULAN}

Berdasarkan hasil penelitian dan pembahasan, penulis memperoleh kesimpulan sebagai berikut:

1. Dampak Pandemi Covid-19 terhadap UMKM Batik di kabupaten Sumenep diantaranya:

a. Penurunan Penjualan

Disaat Pandemi Covid-19 UD. Al Barokah, CV. Batik Tulis Melati, dan Canteng Koneng mengalami penurunan penjualan. Penurunan penjualan yang dialaminya akan berimbas pada para pengrajin dan karyawan yang bekerja di UMKM tersebut. Dimana UD. Al Barokah dan CV. Batik Tulis Melati telah memberhentikan para karyawan dan pengrajin yang bekerja. Namun tindakan untuk memberhentikan para karyawan dan pengrajin dimasa pendemi Covid-19 tidak dilakukan oleh pemilik Canteng Koneng. Penurunan penjualan yang dialami oleh UD. Al Barokah, CV. Batik Tulis Melati dan Canteng Koneng disebabkan adanya penerapan PSBB dan tutupnya sektor pariwisata.

b. Perolehan Bahan Baku

Kendala pada saat perolehan bahan baku telah dialami oleh pemilik UD. Al Barokah dan Canteng Koneng. Dimana UD. Al Barokah mengalami kendala kenaikan harga pada saat perolehan bahan baku. Sedangkan Canteng Koneng mengalami kendala telatnya pengiriman bahan baku. Kendala pada saat perolehan bahan baku tidak dialami oleh pemilik CV. Batik Tulis Melati.

c. Penagihan Piutang

Kendala dalam penagihan piutang saat ini telah dialami oleh UD. Al Barokah. Adanya Pandemi Covid-19 dapat dijadikan suatu alasan oleh pelanggan untuk menunggak pembayaran piutang. Hal tersebut disebabkan karena pelanggan ataupun agen saat ini terdampak Covid- 19 sehingga mereka tidak mampu untuk membayar piutang mereka

kepada UD. Al Barokah. Kendala dalam penagihan piutang tidak dialami oleh CV. Batik Tulis Melati dan Canteng Koneng.

d. Pembayaran Gaji Karyawan

UD. Al Barokah dan Canteng Koneng pernah mengalami kendala dalam membayar gaji karyawan. Hal tersebut terjadi karena saat itu tidak ada pendapatan akibat tidak adanya permintaan dari konsumen. Demi mengurangi beban operasionalnya UD. Al Barokah dan Canteng Koneng menunda pembayaran gaji karyawan untuk sementara waktu. Kendala terhadap pembayaran gaji karyawan tidak dialami oleh CV. Batik Tulis 
Melati, karena selama masa Pandemi Covid-19 proses produksi dihentikan karena tidak adanya permintaan dari konsumen.

2. Saat ini UD. Al Barokah, CV. Batik Tulis Melati, dan Canteng Koneng menggunakan media sosial untuk memasarkan produknya secara online. Pemasaran secara online dilakukan agar usahanya tidak stagnan akibat adanya Pandemi Covid-19 dan tetap menjalin komunikasi dengan konsumen, serta mempromosikan produk barunya karena disaat Pandemi Covid-19 tidak ada kunjungan dari para wisatawan.

3. Pemilik UD. Al Barokah dan CV. Batik Melati tidak mengharapkan bantuan dari pemerintah terhadap usahanya. Justru pemilik UD. Al Barokah berharap adanya bantuan untuk UMKM yang usahanya masih kecil dan para pengrajin yang diberhentikan. Adanya bantuan kepada pengrajin juga diharapkan oleh pemilik CV. Batik Tulis Melati. Beda halnya dengan pemilik Canteng koneng yang berharap agar pemerintah dapat mencari solusi untuk membantu UMKM disaat Pandemi Covid-19. Bantuan yang diinginkan oleh pemilik Canteng Koneng terhadap usahanya berupa bahan bahan baku dan bantuan biaya operasional produksi. Saat ini pemerintah telah mengeluarkan stimulus fiskal untuk membantu UMKM. Bantuan dari pemerintah yang diterima oleh UD. Al Barokah, CV. Batik Tulis Melati, dan Canteng Koneng berupa stimulus untuk restrukturisasi kredit.

\section{REFERENSI}

Alwiyah. 2017. Batik Madura Sejarah Jati Diri Dan Motif. Sumenep. Universitas Wiraraja Sumenep.

Ananda, C. F. (2020). Peran Kebijakan Fiskal Bagi Umkm Di Masa Pandemi Covid-19. ISEI Madura.

Darmanto, Wardaya, dkk. 2018. Sekilas Usaha Mikro Kecil Dan Menengah Kiat Mempercepat Kinerja UMKM Dengan Model Strategi Orientasi Berbasis Lingkungan. Yogyakarta. Grup Penerbitan CV Budi Utama.

Hadad, M. (2020). What We Can Do for SMEs. ISEI Madura.

Islamy, I. (2010). Prinsip-Prinsip Perumusan Kebijakan Negara. Lampung. Bumi Aksara.

Rachbini, D. J. (2020). UMKM Di Masa Pandemi Covid-19. ISEI Madura.

Sarjono, Sigit. 2017. Ekonomi Mikro Teori Dan Aplikasi. Yogyakarta. Andi (Anggota IKAPI).

Sugiono. 2019. Metode Penelitian Kuantitatif Kualitatif. Bandung. Alfabeta.

Suharyadi, Harissetyanto, Nugroho, dkk. 2007. Kewirausahaan Membangun Usaha Sukses Sejak Usia Muda. Jakarta. Salemba Empat. 